\title{
UNDERSTANDING NATURAL REGENERATION IN BURNED TROPICAL PEATLAND: A STRATEGY TO ACCELERATE THE FOREST RECOVERY PROCESS
}

\author{
DWI PUJI LESTARI*, TARYONO DARUSMAN, FRANSISKUS A. HARSANTO, \\ DESRA ARRIYADI AND GINANJAR \\ Katingan-Mentaya Project, PT Rimba Makemur Utama, Jalan Kantin No. 8, Bogor 16121, Indonesia
}

Received 11 February 2020/Accepted 17 June 2020

\begin{abstract}
The 2015 massive forest fires across Central Kalimantan left large areas of burned peatlands that need to be restored, demanding substantial resources. To understand natural regeneration of burned peatland and how planting might accelerate its recovery process, the regrowth of burned peatlands was measured with different fire frequencies. Three transects were established. Each transect consisted of five $20 \times 20 \mathrm{~m}$ plots with $30 \mathrm{~m}$ intervals. All woody species were recorded and classified into three categories as new regrowth, regrowth, and remnant trees that survive from the last fire. In addition, data from fifteen $2 \times 2 \mathrm{~m}$ permanent natural regeneration plots and evaluation on survival rate of 2017 planting were also analyzed. Research results suggested that the absence of remnant trees due to frequent or severe fires does not always impede the emergence of new recruitments, although diversity of forest regrowth is likely to be affected by its proximity to forest remnants. The floristic composition also showed a domination of pioneer species, giving evidence that forest recovery is initiated. Our study indicated that the combination of fire frequency, fire intensity, and proximity to remnant forest will produce different degrees of forest recovery, and the result will be unique for each site. It is concluded that to support the recovery process through planting activity, the successional stage of the designated sites should be determined first. The common planting method on large areas with mixed climax-high valuable trees was not beneficial unless the restoration sites had reached the later stages of succession.
\end{abstract}

Keywords: natural regeneration, peatland fire, restoration, succession, tropical peatland

\section{INTRODUCTION}

Indonesian peatlands account for 14.91 million ha and contribute to more than $35 \%$ of the world's peatlands (Osaki et al. 2016). However, although peatlands store a substantial amount of carbon compared to other land uses and provide important hydrological services to the surrounding areas, their presence is threatened by human disturbance, especially due to the need to clear vegetation for agricultural lands (Page et al. 2009). Osaki et al. (2016) stated that the agricultural activity on peatlands in Indonesia has a long and complex historical substance, with fires playing an important role in

"Corresponding author, email: dwi.puji@ptrmu.com this story, although fire is not likely naturlly occurred on peat swamp forest ecosystem. Fires have been commonly used to clear peatland forests, and this such burning become massive in areas whenever a long drought occurs, such as in commonplace during El Nino climatic phases (Page et al. 2009; Shiodera et al. 2016).

From 1990 to 2015, about $61 \%$ of Indonesia's peatland forests were lost or damaged, with only $6 \%$ of virgin peatland forest remaining by 2015 (Graham et al. 2017). The last massive forest fire in Indonesia was in 2015, which burned 2.6 millions ha of lands, where $33 \%$ of them were peatlands (Glauber \& Gunawan 2015). Noxious haze and tonnes of greenhouse gases (GHGs) were released, catching national and international attention as well as raising awareness. 
This disaster spurred the needs for better efforts in peatland restoration and fire prevention. Unfortunately, planting on such a remote and wide landscape requires a substantial amount of capital, ranging from 500 to 3500 USD per hectare (Giesen \& Sari 2018). On the other hand, relying on natural regeneration unlikely to be enough as it may result in low diversity (Blackham et al. 2014). Moreover, unlike numerous studies on dryland or tropical forests, studies on the recovery process of peatland after fire are less common or still at their early stage (Graham et al. 2017; Page et al. 2009; Shiodera et al. 2016). This results in considerable uncertainties around the effectiveness of current peatland restoration practice.

The hypothesis was that the result of forest recovery over times will vary depending on the fire frequency, fire intensity, and proximity to remnant forest. To assess the vegetation recovery process and succession on recently burned peatland, their natural regeneration on sites which have different fire history and proximity to the nearest remnant forest was measured. Species composition and diversity after fires were compared, and the effects of the current practice of tree planting on peatland restoration was investigated. Specifically, this study aimed to investigate whether the common practices on peat forest revegetation were parallel with natural process of forest succession. Moreover, this study was part of an ongoing vegetation survey focuses on peat swamp forest succession after fire. This study only examined vegetation or floristic component of peatland restoration, while restoration related to the hydrological function and other components of biodiversity are not covered.

\section{MATERIALS AND METHODS}

\section{Study Location}

The study was conducted along the big canal on the southern area of the ecosystem restoration concession of PT Rimba Makmur Utama, also known as the Katingan-Mentaya Project, Katingan District, Central Kalimantan located at $2^{\circ} 32^{\prime} 36.8^{\prime \prime} \mathrm{S}$ to $3^{\circ} 01^{\prime} 43.6^{\prime \prime} \mathrm{S}$ and $113^{\circ} 00^{\prime} 29.7^{\prime \prime} \mathrm{E}$ to $113^{\circ} 18^{\prime} 57.4^{\prime \prime} \mathrm{E}$ (Fig. 1). The study location is a typical degraded peatland forest mostly damaged by logging activities in the late 1970 s to early 2000 s, and subsequent canal drainage mainly for agricultures and transportation network, as well as forest fires. Peat depth on the study location ranged from $300 \mathrm{~cm}$ to $450 \mathrm{~cm}$, with annual precipitation of about $2820 \mathrm{~mm}$ (information was collected from the weather station at Haji Assan Sampit Airport by Rossita et al. (2018).

In the late 1990s, the Public Works Agency (Dinas Pekerjaan Umum) constructed a $24 \mathrm{~km}$ long canal to connect Kotawaringin Timur and Katingan District. Nowadays, about $6 \mathrm{~km}$ of the canal cuts across the restoration concession and has become the main cause of the surrounding peat drainage. Before the concession was granted in 2013, fires occurred almost annually along the banks of the canal. Vegetation along the canal is dominated by ferns and shrubs, with a few clumps of pioneer species. 


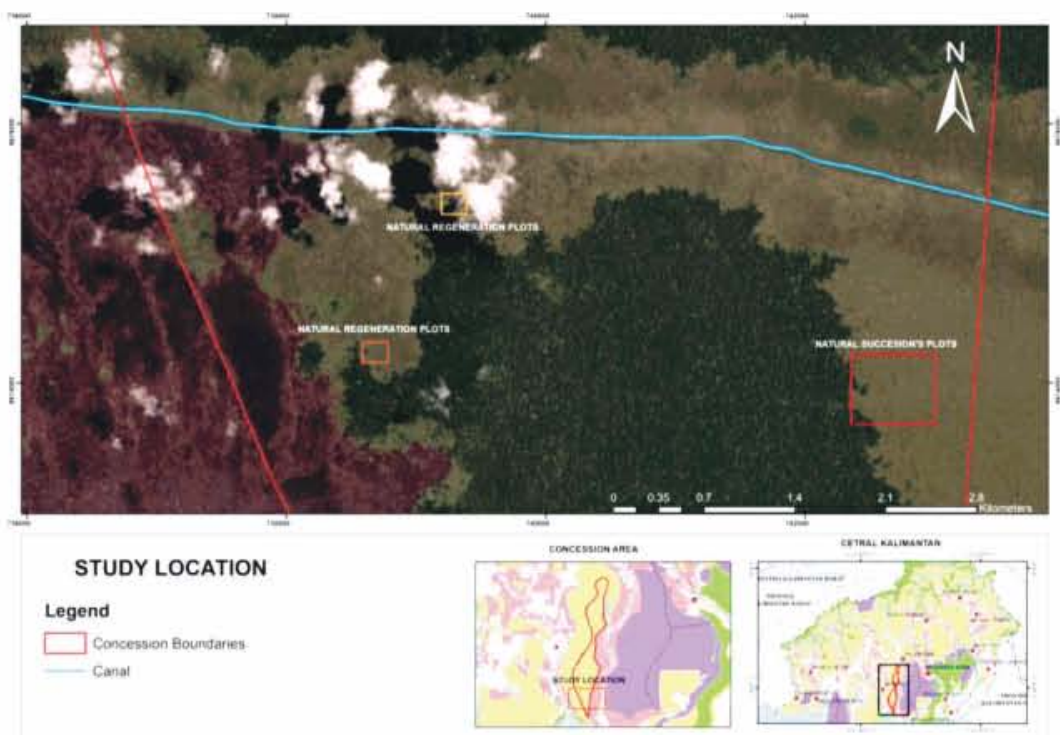

Figure 1 Map of the study location on the ecosystem restoration concession Note: The map was displayed using Planet Lab satellite image year of 2017.

\section{Plot Observation and Data Analysis}

\section{Natural Succession Plots}

Three transects within the natural succession observation site (Fig. 1) were developed in April 2018 on the southeast part of the canal to observe natural regeneration of peatland forest after fires. The first transect (transect FB, frequently burned) was located on an area that was close to the canal ( $0.5 \mathrm{~km}$ distance). It was burned three times in the period of 2010-2015 and was far from the forest edge $(1.5 \mathrm{~km}$ distance). The second transect (transect FBF, frequently burned, close to forest edge) was also burned three times in between those years but was located far from the canal (1 km distance) and near to the forest edge on the west side of the transect. The last transect (NB, newly burned) has never been burned before 2014 and only caught fire once in 2015. This transect was also isolated from the nearest canal and forest edge. Before the attack of frequent fires, the land cover of the three transects was a secondary forest. Details regarding the fire history of the study location can be seen in Table 1.

Five $20 \times 20 \mathrm{~m}$ plots were established on each transect (Fig. 2). Each plot was located $30 \mathrm{~m}$ away from each other. In total, 15 observation plots $(0.6 \mathrm{ha})$ were measured in this study. Within each plot, all woody plants were counted and measured in terms of their bole diameter (if plant height is less than $1.3 \mathrm{~m}$ ) or diameter at breast height ( $\mathrm{dbh}$, if plant height is $1.3 \mathrm{~m}$ or more). Local names were identified on the field by a well-trained local botanist and their scientific names were identified using the guide book of PT Rimba Makmur Utama. During the observation, all transects were covered by shrubs and ferns with patchy pioneer tree species (Fig. 2). Both ferns and shrubs are typical species that emerge on peat ecosystem after fire such as Stenochlaena palustris and Cyperus rotundus with a height of more than $2 \mathrm{~m}$.

Analysis was then conducted by dividing all woody plants into three classes: 1 . new regrowth, which included all woody plants with height $\leq 150 \mathrm{~cm}$ that were assumed to emerge later after fire; 2. regrowth, which included all woody plants with height $>1.5 \mathrm{~m}$ and $\mathrm{dbh}<10$ $\mathrm{cm}$ that were assumed to emerge soon after the fire in 2015 ; 3. survivor, which included the remaining trees surviving from the last fire with $\mathrm{dbh} \geq 10 \mathrm{~cm}$. Species composition, density, species richness (Shannon's diversity index), and species evenness (Pielou's evenness index) were analyzed to examine the structure and composition of the existing natural regeneration and stage of the succession process. Bray-Curtis dissimilarity index and NMDS ordination were also calculated to understand the pattern of species composition among transects and acquire the notable species within each study site. All analyses were performed using $\mathrm{R}$ version 3.4.0 with vegan package 2.4-3 (Oksanen et al. 2017). 
Table 1 Fire history on the three transects from 2010 to 2018

\begin{tabular}{cccc}
\hline & \multicolumn{3}{c}{ Fire History $(\sqrt{ }$ symbol means there was fire in the conspecific year $)$} \\
\cline { 2 - 4 } 2010 & Transect FB & Transect FBF & Transect NB \\
2011 & $\sqrt{ }$ & $\sqrt{ }$ & - \\
2012 & - & - & - \\
2013 & - & - & - \\
2014 & - & - & $\sqrt{ }$ \\
2015 & $\sqrt{ }$ & - & - \\
2016 & - & - & - \\
2017 & - & - & - \\
\hline
\end{tabular}

Notes: Fire and hotspot data were analyzed from Landsat 5, 7,8 and Sentinel 2 satellite images. Each image on each year were displayed on composite mode using similar band combination of SWIR, NIR and Green, and hotspot historical data acquired from National Institute of Aeronautics and Space of Indonesia (LAPAN) website were overlaid.
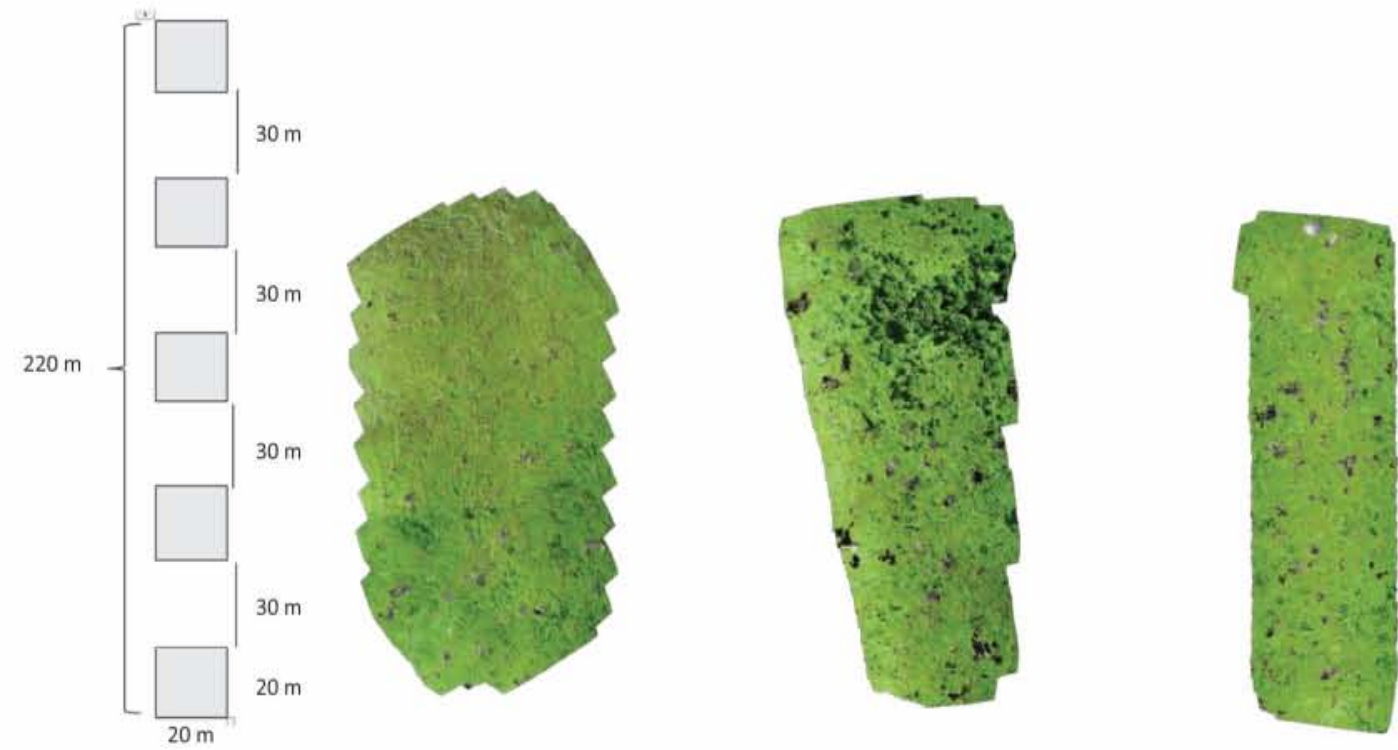

Figure 2 Layout of observation plots within transects and view of land cover from transect FB (left), FBF (middle), and NB (right) observed with drone DJI Phantom pro 4 in April 2018

\section{Natural Regeneration Plots}

In total, fifteen $2 \times 2 \mathrm{~m}$ permanent plots were established within the ecosystem restoration concession area of PT Rimba Makmur Utama, which was distributed on the southern part of the canal (Fig. 1, natural regeneration plots). Plots were located on degraded peatland that burned almost annually before 2015. The last fire incidence was in 2014. In 2015, these plots were established, and all seedlings less than $1.5 \mathrm{~m}$ in height were recorded every six months. The trend of natural regeneration composition from year to year was then analyzed to examine the typical species that appear after fires on peatland forest.

\section{Tree Plantings on Degraded Peatland}

As an ecosystem restoration concession, the concession is responsible for planting activity on their areas, and the result is monitored periodically. In January 2017, in total, 19,670 seedlings of local tree species were planted. About $2.5 \%$ of seedlings were monitored and the survivor rate was calculated in 9 months and 17 months after planting. 


\section{RESULTS AND DISCUSSION}

\section{Species Composition on Different Sites}

Fires that attacked the study area resulted in the low density of remaining trees, as shown in Figure 3. Transect FB likely received a higher degree of fire incidence as only 5 trees/ha were left on this site, while transects FBF and NB had higher density and more diverse remnant tress (Fig. 4). The study results suggested that the proximity to main canal influenced the intensity of fire, where fires normally started from the surrounding canal. Transect FBF had the highest density and more surviving tree species, possibly due to the lower severity of fire on this site, as well as its proximity to the forest edge. In addition, based on our observation, limited number of surviving trees indicated that those native climax-species were mostly not equipped with natural mechanism to survive under fires, as fire was not a natural phenomenon in tropical peat swamp environment unlike in dry sclerophyll forests where fires could occur naturally. The only protection was the wet and inundated peat environment that mostly absent when peat was drained.

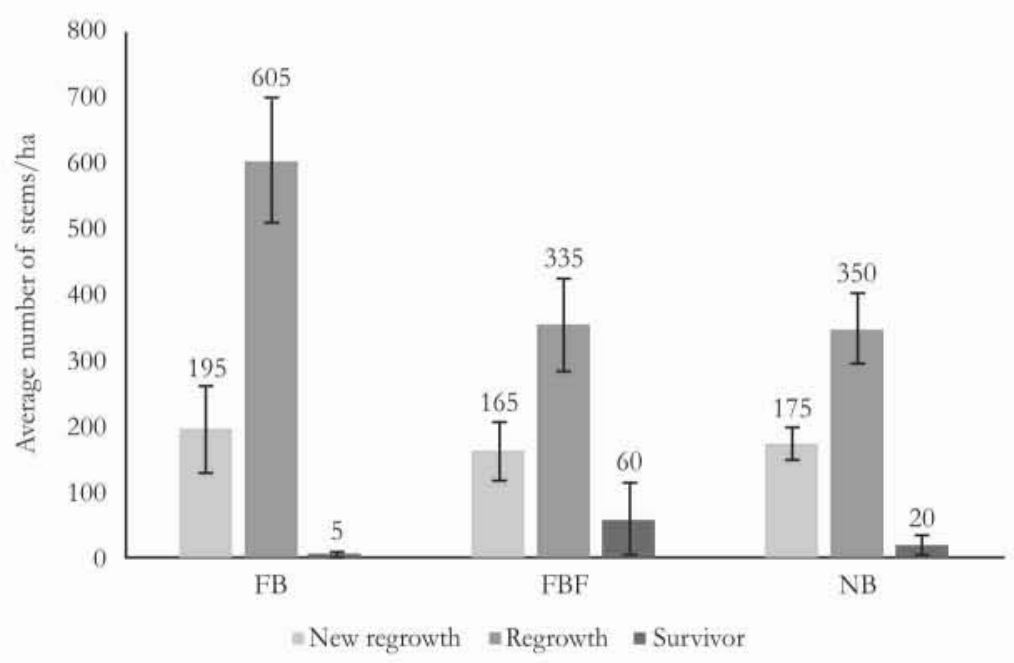

Figure 3 The average density of woody species on different locations

Notes: transect FB: frequently burned, close to canal, far from forest; transect FBF: frequently burned, far from canal, close to forest edge; transect NB: only burned once in 2015 , far from forest and canal, divided by three size classes: new regrowth, regrowth, and survivor. Error bars indicated standard error.

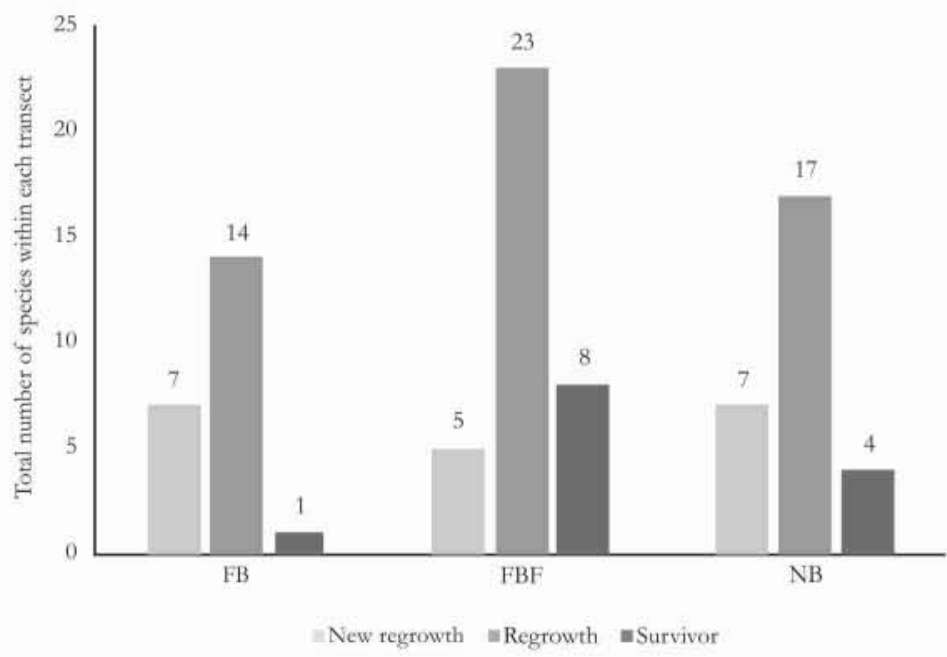

Figure 4 Number of species on different locations

Notes: transect FB: frequently burned, close to canal, far from forest; transect FBF: frequently burned, far from canal, close to forest edge; transect NB: only burned once in 2015, far from forest and canal, divided by three size classes: new regrowth, regrowth, and survivor. 
It is likely that the availability of survivor trees does not guarantee the emergence of new recruitments, although Cleary and Priadjati (2005) stated that the presence of remnant trees might be important to accelerate the succession process. Three years after the last fire incidence in 2015, recruitments of woody species were abundant on the three transects. Even though only a small number of remaining trees were present on transect $\mathrm{FB}$, recruitments on this site were very dense (in total 800 recruitments/ha appeared after the 2015 fire) compared to transect FBF and transect NB. On the other hand, although higher recruitment density can be found on transect FB, the density itself is not parallel to the species diversity, which is relatively low at transect $\mathrm{FB}$. The 800 recruitments/ha on this transect were composed of 21 species only, while transects FBF and NB contained 28 and 24 species of recruitments, respectively.

This indicates that the density of the remnant trees after fire might not affect the emergence of new recruitments on peatland forest, as a source of seeds might come from various sources. Seedbanks were likely absent due to frequent fires, but sources of seeds were possibly supplied from the nearest sites by their dispersal agents. Therefore, proximity to the remnant forest is expected to play an important role to increase diversity of these recruitments. This is supported by higher Shannon' diversity index (Table 2) on transect FBF compared to other transects. This is consistent with Chazdon (2008) who stated that the nature of forest recruitments after disturbance is often determined by features of its local landscape.

Bray-Curtis dissimilarity index calculation among the three transects also indicated that transect FB was the least similar compared to the other two transects, while transects FBF and NB share more similarities (Table 3). The NMDS ordination displayed clearer segregation by showing that transect FB tends to segregate from the rest of the transects. This transect was characterized with more long-lived pioneer species, such as Melaleuca leucadendron, Melicope lunu-ankenda, Sysygium sp., and Macaranga pruinosa, while transects $\mathrm{FBF}$ and $\mathrm{NB}$ were also rich with other generalist and late successional species, such as Alstonia scholaris, Ficus spp., and Nephelium mangayi. Unlike other researchers who reported that burned peatland forests in Kalimantan were normally dominated by pioneer species especially Combretocarpus and Cratoxylum species (Blackham et al. 2014; Graham et al. 2017; Shiodera et al. 2016), there were no indications about the existence of these species in our study sites. However, it is confirmed that our study sites were still at the early stage of forest succession as most species that were supposed to be present in undisturbed peat swamp forests as mentioned by Mirmanto (2010) were absent. Moreover, Mirmanto (2010) also reported that at least 2,000 trees/ha with more than 30 species could be found within 0.25 ha area of burned peatland. This indicated that the density of regrowth on our study site was still relatively low although the species richness (especially on FBF) demonstrated a valuable sign of recovery.

Table 2 Shannon's diversity index (H') and Pielou's evenness (E') on different locations

\begin{tabular}{llccc}
\hline & Site & New regrowth & Regrowth & Survivor \\
\hline $\mathrm{H}^{\prime}$ & FB & 1.5 & 1.8 & 0.0 \\
& FBF & 1.1 & 2.6 & 1.8 \\
& NB & 1.2 & 2.1 & 1.4 \\
& All sites & $\mathbf{1 . 5}$ & $\mathbf{2 . 5}$ & 0.0 \\
$\mathrm{E}^{\prime}$ & FB & 0.8 & 0.7 & 0.9 \\
& FBF & 0.7 & 0.8 & 1.0 \\
& NB & 0.6 & 0.7 & $\mathbf{0 . 9}$ \\
\hline
\end{tabular}

Notes: Transect FB: frequently burned, close to canal, far from forest; transect FBF: frequently burned, far from canal, close to forest edge; transect NB: only burned once in 2015, far from forest and canal, divided by three size classes: new regrowth, regrowth, and survivor. 
Table 3 Bray Curtis dissimilarity index among the three transects

\begin{tabular}{ccc}
\hline Bray Curtis Dissimilarity Index & FB & FBF \\
\hline FBF & 0.610 & \\
NB & 0.607 & 0.467 \\
\hline
\end{tabular}

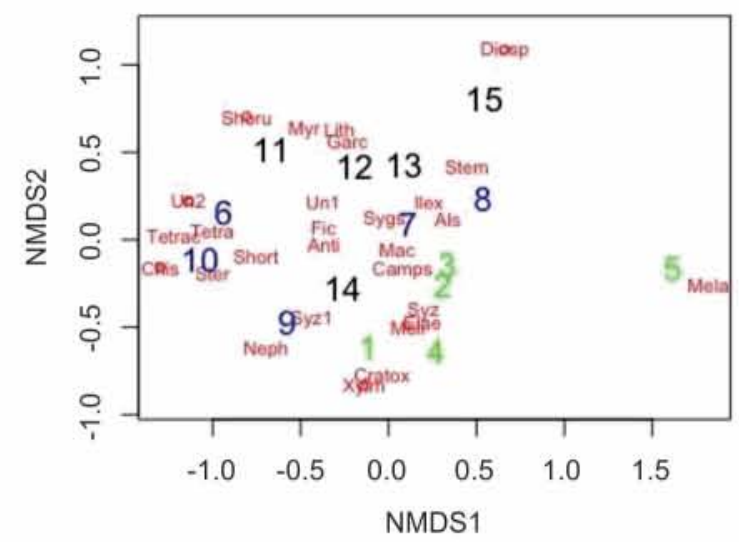

Figure 5 Non-metric multidimensional scaling (NMDS) ordination with stress value $<0.2$, showing that this ordination displays a fair representation of species composition on each plot. Plots 1-5 are plots on FB transect, while plots 6-10 and 11-15 are located on FBF and NB transects, respectively

Moreover, our study indicated that fires frequencies are not the only determining factor on forest recruitment on this study site, although according to Shiodera et al. (2016), intense and repeated fires reduced the ability of forests to regenerate. The combination of fire frequency, fire intensity, and proximity to remnant forest will produce different degrees of forest recovery, and the result will be unique for each site (Graham et al. 2017). Our study showed that frequent fires might not impede new recruitments. However, proximity to the nearest forest edge might impact the diversity of regrowth. This is because proximity to forest remnant plays an important role in producing seeds to ensure the continuous emergence of recruitments. For example, despite receiving frequent fires in the last nine years, transect FBF recruits more diverse regrowth compared to transect NB which was burned just once in 2015. Another study on ex Mega Rice Project in Central Kalimantan also stated that natural regeneration on isolated degraded peatlands resulted in slow and patchy regrowth with low diversity (Blackham et al. 2014).

\section{Vegetation Recoveries Over Times and Impact on Peatland Restoration}

Table 4 shows that new recruitments after fires on the three transects were dominated by pioneer species, which seeds were mostly dispersed by wind or birds, or sourced from dormant seedbank within the peat layer. Only few resproutings were found and mostly appeared from Ficus spp. It is supported by Chazdon (2008) that initial succession is normally composed of long-lived pioneer species that change slowly over times. Moreover, Table 4 also displayed a phenomenon that most recruitments were not conspecific to the remaining trees that survive after fire. For example, the presence of a few Dipterocarp trees on transect NB was not followed by the emergence of seedlings from these species. Once again, our study showed that abundant mother trees would not give a substantial advantage on recruitments unless they are able to regenerate. The presence of climax species such as Shorea spp., would not likely support initial forest recovery as these species are not able to produce continuous seeds for regeneration due to limited pollination (Ghazoul 2005), and if they are able, seedlings of climax species might find it hard to survive due to extreme heat and sun radiation on a typical open peatland.

As the forest recovery process starts with colonization (Chazdon 2008), the key to peatland vegetation recovery after fires is to enable vegetation colonization as soon as 
Table 4 The four most dominant species within each transect

\begin{tabular}{llll}
\hline & \multicolumn{1}{c}{ Transect FB } & \multicolumn{1}{c}{ Transect FBF } & \multicolumn{1}{c}{ Transect NB } \\
\hline New Regrowth & Alstonia scholaris & Campnosperma coriaceum & Alstonia scholaris \\
& Melicope lunu-ankenda & Alstonia scholaris & Campnosperma coriaceum \\
& Campnosperma coriaceum & Ficus spp. & Melicope lunu-ankenda \\
& Macaranga pruinosa & Nephelium mangayi & Sysygium spp. 2 \\
Regrowth & Melicope lunu-ankenda & Elaeocarpus acmocarpus & Alstonia scholaris \\
& Melaleuca sp. & Macaranga pruinosa & Melicope lunu-ankenda \\
& Campnosperma coriaceum & Campnosperma coriaceum & Ficus spp. \\
& Alstonia scholaris & Tetractomia obovata & Syygium spp. 2 \\
Survivor & Campnosperma coriaceum & Tetractomia obovata & Myristica iners \\
& & Alstonia scholaris & Shorea teysmanianna \\
& & Campnosperma coriaceum & Shorea uliginosa \\
& & Elaeocarpus acmocarpus & Tetractomia obovata \\
\hline
\end{tabular}

possible, and this depends on the availability of regeneration sources (seeds or resproutings). Unfortunately, heavily degraded peatlands are commonly dominated by high and dense ferns and shrubs that impede other woody species to grow (Page et al. 2009). Given this condition, only pioneer species are able to grow and supply continuous seeds for further colonization (Hapsari et al. 2018; Shiodera et al. 2016). Only when this condition is achieved, late successional species might then be able to emerge dispersed by birds or bats, and bring the recovery process to the next stage.
This finding is supported by our observation on 15 of the $2 \times 2 \mathrm{~m}$ permanent plots of natural regeneration (Fig. 6). These plots were burned almost at an annual basis, with the last fire incidence being in 2014. From this figure, several pioneer species (Melaleuca leucadendron, Melicope lunu-ankenda, Syyygium sp.) dominated the whole study area. However, in the third year, late successional and generalist species (Campnosperma coriaceum, Alstonia scholaris, Ctenolophon parvifolius) started to appear, although pioneer species still dominated.

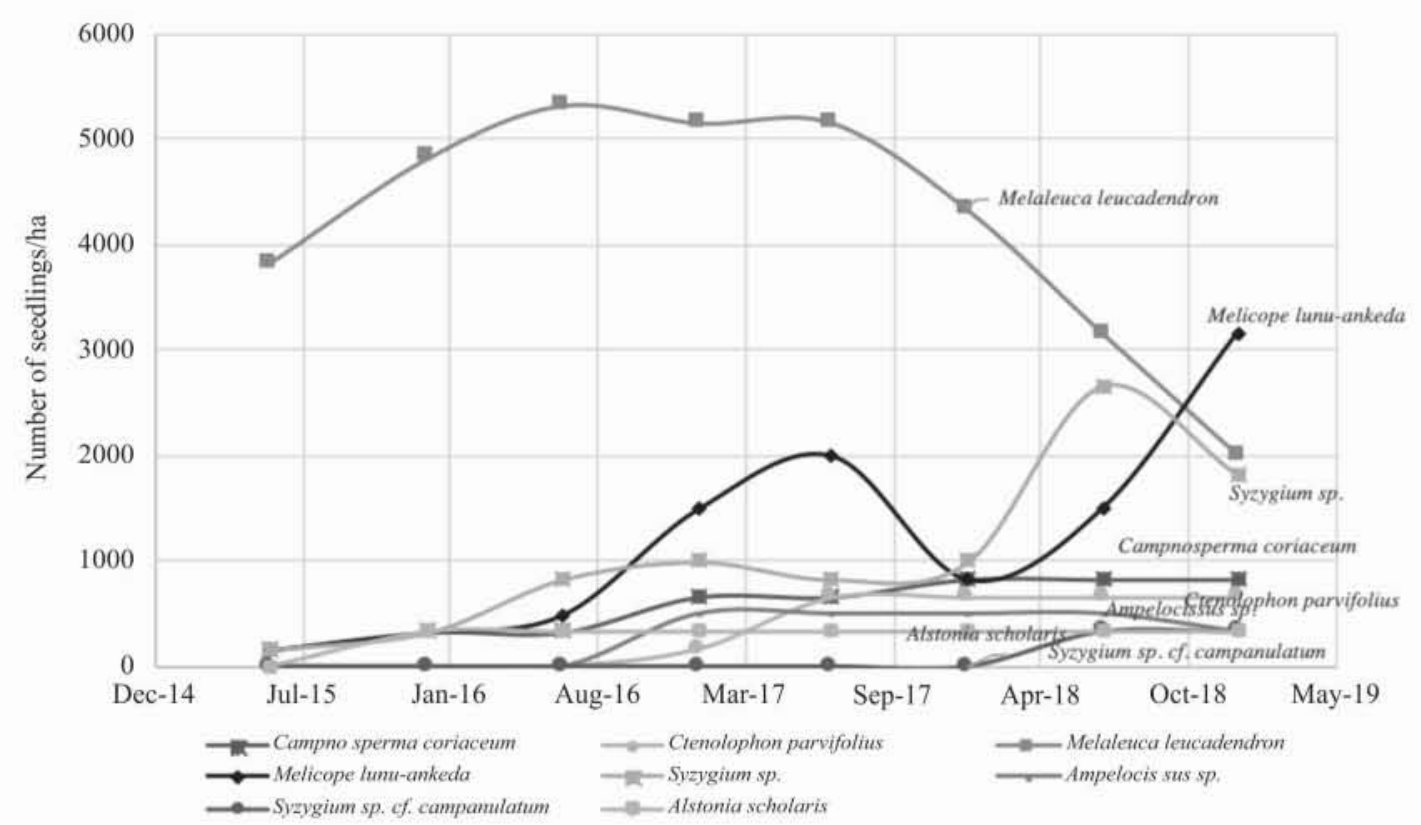

Figure 6 Trend of recruitments on the smaller natural regeneration permanent plots, observed from 2015 to 2018 Note: The last fire attack was in 2014 , and before that year, all plots were almost annually burned. 
The evidence that only pioneer species are able to secure the stand initiation process asks a question to the common technique of vegetation restoration on degraded peatland forest in Indonesia. Common practice normally involves line or blanket planting on a large area with a mix of pioneer and climax species regardless of their ability to produce continuous seed sources and resprouting ability for rapid colonization. Planting also normally prioritizes high economic value species or rare species which are beneficial only when they are purposed for enrichment planting after the first stage of the successional phase (stand initiation) is achieved. A paleocological study by Hapsari et al. (2018) stated that floristic composition in degraded peat-swamp forest in Sumatra can passively recover, and this is marked by initial domination of rapidly generating trees such as Gnetum, Calophyllum, Sapotaceae, and Ficus to assure tree colonization and finally enable other late successional species to naturally establish either dispersed by bats or birds.

Our examination in 9 and 17 months after planting various mixed species, showed that pioneer species had a much higher survival rate and so dominated the revegetation (including species such as Alstonia, Combretocarpus, and Sysygium), and only a few late successional-high valuable tree species (such as Dyera, Diospyros, and Shorea) were found (Figure 7). Moreover, our findings showed higher overall survival rates compared to another trial planting experiment by Tata (2017), and slightly lower rates compared to a study by Lampela et al. (2017).

Our study suggested that planting late successional as well as high valuable tree species, without examining first which the successional stage the site is in, is unnecessary. Although some species with high commercial value are able to grow on the initial phase of forest recovery, however, as previously mentioned, it will not give any beneficial value if those species are not able to produce continuous regeneration for stand initiation process. However, late successional or climax species could still be incorporated in the initial planting but with smaller number compared to the pioneer species. Again, these climax species are beneficial for enrichment planting only, where the planting purpose is to increase species diversity on a site that has passed the first phase of the successional process. Therefore, to increase the effectiveness of the forest recovery process on recently burned peatland, planting rapidly regenerating or pioneer species to ensure stand colonization is highly recommended.

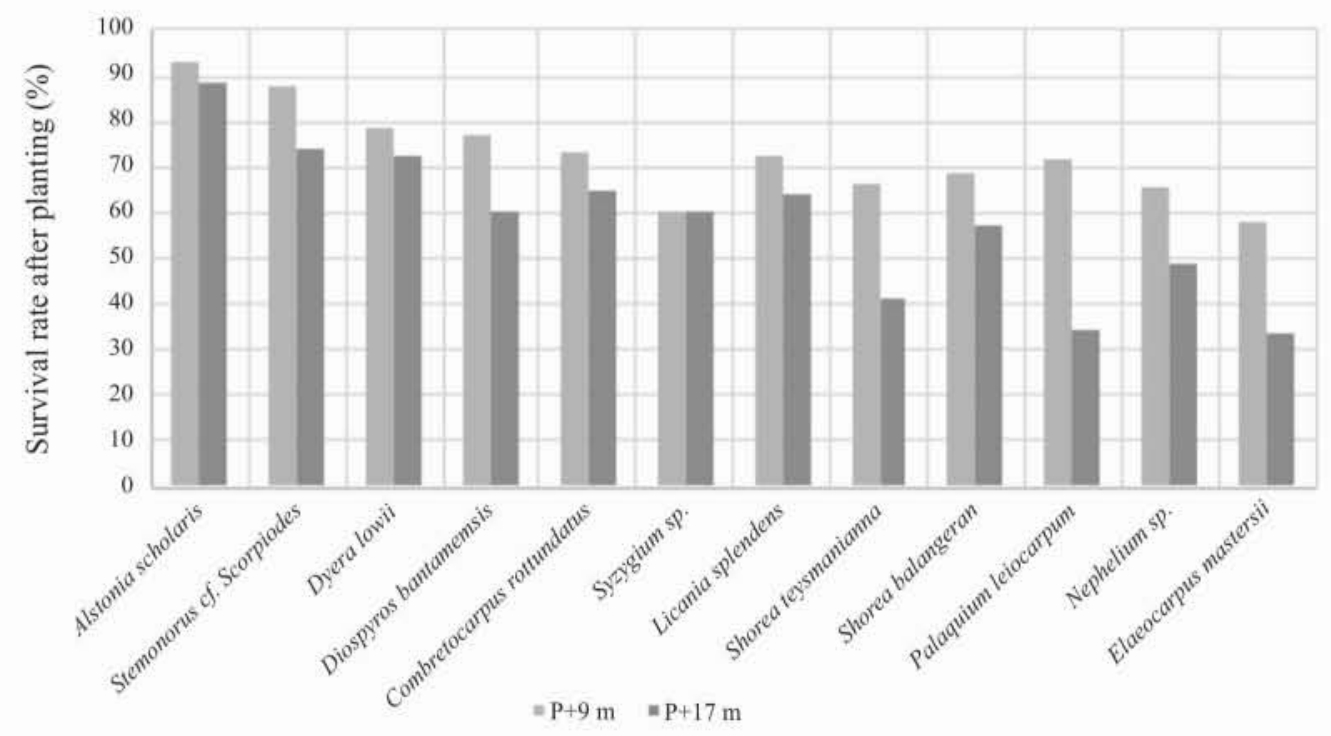

Figure 7 Survival rate of tree seedlings calculated in 9 months after planting $(P+9 \mathrm{~m})$ and 17 months after planting $(\mathrm{P}+17 \mathrm{~m})$ 


\section{CONCLUSION}

To ensure the forest recovery process, forest colonization with species that can produce continuous species accumulation, either by sprouting or producing seed sources, needs to be addressed first. The common method of restoration practice using expensive species that cannot guarantee continuous self-regeneration is unbeneficial unless the restoration sites have reached the later stage of succession. The successional stage of the designated area should be determined first, as planting should focus on species that meet the needs of the successional stage on the designated sites. To ensure forest recovery, vegetation restoration on peatland should be parallel with hydrological restoration and fire prevention.

\section{ACKNOWLEDGEMENTS}

We wish to acknowledge all field staff of PT Rimba Makmur Utama who helped the authors undertake routine data collection in the field, and local communities who enrich our insight on the peatland forest ecosystem with their important-original knowledge.

\section{REFERENCES}

Blackham GV, Webb EL, Corlett RT. 2014. Natural regeneration in a degraded tropical peatland, Central Kalimantan, Indonesia: Implications for forest restoration. Forest Ecology and Management, 324, 8-15. https://doi.org/10.1016/ j.foreco.2014.03.041

Chazdon RL. 2008. Chance and determinism in tropical forest succession. In: Carson WP, Schnitzer SA, editors. Tropical Forest Community Ecology. London: Willey-Blackwell. p. 384-408.

Cleary DFR, Priadjati A. 2005. Vegetation responses to burning in a rain forest in Borneo. Plant Ecology, 177(2), 145-163. https://doi.org/10.1007/s11258005-2107-0

Ghazoul J. 2005. Pollen and seed dispersal among dispersed plants. Biological Reviews, 80(3), 413443. https://doi.org/10.1017/S1464793105006731

Giesen W, Sari ENN. 2018. Tropical Peatland Restoration Report: the Indonesian case. https://doi.org/ 10.13140/RG.2.2.30049.40808
Glauber AJ, Gunawan I. 2015. The cost of fire. An economic analysis of Indonesia's 2015 fire crisis. In: The World Bank (Vol. 17).

Graham LLB, Giesen W, Page SE. 2017. A commonsense approach to tropical peat swamp forest restoration in Southeast Asia. Restoration Ecology, 25(2), 312-321. https://doi.org/10.1111/ rec. 12465

Hapsari KA, Biagioni S, Jennerjahn TC, Reimer P, Saad A, Sabiham A, Behling H. 2018. Resilience of a peatland in Central Sumatra, Indonesia to past anthropogenic disturbance: Improving conservation and restoration designs using palaeoecology. Journal of Ecology, 106(6), 24732490. https://doi.org/10.1111/1365-2745.13000

Lampela M, Jauhiainen J, Sarkkola S, Vasander H. 2017. Promising native tree species for reforestation of degraded tropical peatlands. Forest Ecology and Management 394:52-63. https://doi.org/ 10.1016/j.foreco.2016.12.004

Mirmanto E. 2010. Vegetation analyses of Sebangau peat swamp forest, Central Kalimantan. Biodiversitas, Journal of Biological Diversity 11(2):82-8. https://doi.org/10.13057/biodiv/d110206

Oksanen AJ, Blanchet FG, Friendly M, Kindt R, Legendre P, Mcglinn D, ... Szoecs E. 2017. Package 'vegan'.

Osaki M, Nursyamsi D, Noor M, Wahyunto, Segah H. 2016. Peatland in Indonesia. In: Osaki M. Tsuji N, editors, Tropical Peatland Ecosystem, Tokyo (JP):: Springer. p. 33-48.

Page S, Hosciło A, Wösten H, Jauhiainen J, Silvius M, Rieley J, ... Limin S. 2009. Restoration ecology of lowland tropical peatlands in Southeast Asia: Current knowledge and future research directions. Ecosystems, 12(6):888-905. https://doi.org/ 10.1007/s10021-008-9216-2

Rossita A, Witono A, Darusman T, Lestari DP, Risdiyanto I. 2018. Water table depth fluctuations during ENSO phenomenon on different tropical peat swamp forest land covers in Katingan, Indonesia. IOP Conference Series: Earth and Environmental Science, 129(1). https://doi.org/10.1088/1755$1315 / 129 / 1 / 012001$

Shiodera S, Atikah T, Apandi I, Seino T, Haraguchi A, Rahajoe J, Kohyama T. 2016. Peat-Fire Impact on Forest Structure in Peatland of Central Kalimantan. In: Osaki M. Tsuji N, editors, Tropical Peatland Ecosystem, Tokyo (JP): Springer. p. 197-212.

Tata HL. 2017. Native Species for Degraded Peat Swamp Forest Rehabilitation. Jurnal Silvikultur Tropika, 7(3):S80-2. 